\title{
Comparison of Volatile Compounds of Chamaecyparis obtusa Essen- tial Oil and its Application on the Improvement of Atopic Dermatitis
}

\author{
Geum-Sook Lim ${ }^{1}$, Ran $\mathrm{Kim}^{2}$, Hoon $\mathrm{Cho}^{3}$, Young-Sook Moon ${ }^{4}$, and Chang-Nam Choi ${ }^{\text {* }}$
}

접수: 2013년 2월 4일 / 게재승인: 2013년 3월 28일

(C) 2013 The Korean Society for Biotechnology and Bioengineering

\begin{abstract}
Volatile flavor compounds of Chamaecyparis obtuse essential oil were extracted by simultaneous steam distillation extraction (SDE) and supercritical fluid extraction (SFE) and analyzed by GC-MS. A total of 48 and 50 components were identified in essential oil by SDE and SFE, respectively. Monoterpenes, oxygenated monoterpenes, sesquiterpenes, oxygenated sesquiterpenes, and diterpenes in essential oil by SDE were $37.24,10.9,9.61,0.22$, and $0.22 \%$, respectively. In the case of SFE, they were 19.1, 23.3, 22.66, 1.31, and $10.57 \%$, respectively. Antioxidant activities were increased with the increase of essential oil up to $80 \mu \mathrm{L} / \mathrm{mL}$, irrespective of extraction method. Especially, when the essential oil concentration extracted by SDE was increased from 20 to $80 \mu \mathrm{L} / \mathrm{mL}$, the antioxidant activity was increased from 10.5 to $55.1 \%$. However, over $80 \mu \mathrm{L} / \mathrm{mL}$ of essential oil, an equilibrium state was maintained. In the case of essential oil extrac-
\end{abstract}

\footnotetext{
${ }^{1}$ 전남대학교 일반대학원 향장품학협동과정

${ }^{1}$ Interdisciplinary Program of Perfume and Cosmetics, Chonnam National University Graduate School, Gwangju 500-757, Korea Tel: +82-62-530-1772, Fax: +82-62-530-1779

e-mail: cnchoi@chonnam.ac.kr

2원광보건대학교 허브테라피향장과

${ }^{2}$ Department of Herb Therapy \& Cosmetics, Wonkwang Health Science University, Jeonbuk 570-750, Korea

${ }^{3}$ 조선대학교 공과대학 응용화학소재공학과

${ }^{3}$ Department of Polymer Science \& Engineering, Chosun University, Gwangju 501-759, Korea

${ }^{4}$ 조선대학교 의과대학 내성세포연구센터

${ }^{4}$ Research Center for Resistant Cells, Chosun University Medical School, Gwangju 501-759, Korea
}

ted by SFE, it was decreased compared to that of SDE. For the improvement of atopic dermatitis, various cosmetics such as an ato-cide soap, ato-cide spray, and ato-cide lotion containing essential oil extracted by SFE were tested. About over $90 \%$ was useful for the improvement of atopic dermatitis after 4 weeks of clinical trial targeting 40 female adults. These results demonstrate that ato-cide soap, ato-cide spray, and atocide lotion containing essential oil extracted by SFE could be used in functional cosmetics.

Keywords: Chamaecyparis obtuse, Essential Oil, Simultaneous Steam Distillation Extraction, Supercritical Fluid Extraction, Antioxidant Activity, Functional Cosmetics

\section{1. 서론}

정유 (essential oil)는 다른 성분에 비하여 미량으로 존재하지 만 기호도 및 제품의 품질 평가에 중요한 영향을 미치며 품 종의 선택에 있어서도 중요한 역할을 한다. 천연물로부터 정 유성분을 분리하는 방법으로는 연속수증기증류법 (simultaneous steam distillation extraction, $\mathrm{SDE}$ ), 용매추출법 (solvent extraction, SE)법, headspace법, 고체상 미세추출법 (solidphase microextraction, SPME) 등 [1]이 있는데, 비교적 열에 안정한 시료인 경우에는 연속수증기증류법이 많이 이용되 고 있고, 고체상 미세추출법은 유기용매를 사용하지 않고 적 은 양의 시료를 간단하게 전처리할 수 있어 최근에 많이 사 용되고 있다 [2]. 특정의 유용 성분을 분리하기 위해 일반적 으로 높은 온도에서 추출용매를 이용한 추출법이 주류를 이 루고 있지만 이는 높은 온도를 장시간 사용해야 함으로써 발 
생하는 유용성분의 변성 및 파괴 등이 야기되고 또한 사용된 용매의 일부가 유용성분에 잔존할 가능성이 있기 때문에 효 과적인 추출법이라고 할 수 없다 [3]. 한편 초임계 유체 추출 법 (supercritical fluid extraction, SFE)은 이와 같은 단점을 보 완하고 기존의 추출방법을 대체할 수 있는 신기술로서 식품, 의약품 및 향료공업에서 특정 성분을 추출분리하기 위하여 많이 이용되고 있으며, 석유공업에서 잔류유 추출, 토양과 수질에 존재하는 유해 유기물의 제거 및 초임계 유체의 빠른 팽창에 의한 초미립자 생성 등에 적용되고 있다. 가장 많이 사용 되는 유체는 이산화탄소로서 불연성 및 무독성이며 임 계온도와 임계압력이 낮아 초임계 상태를 만들기 쉽기 때문 에 최근 식품, 의약, 화장품 등에 널리 사용되고 있다. 또한 초임계유체를 이용한 커피의 카페인과 담배의 니코틴 제거, 호프 엑기스의 추출 등은 이미 산업화되어 있고, 화장품과 식품업계에서는 향료소재 추출에 사용하고 있다 [4-6].

편백나무(Chamaecyparis obtusa)는 열대 수종으로 우리나 라는 남쪽 지방에 잘 생육하며 편백나무 정유는 많은 종류의 테르펜 성분을 함유하고 있으며, 최근에는 편백의 정유 성분 이 다양한 용도로 사용되고 있고 이 수종은 상록 교목으로서 높이 $40 \mathrm{~m}$, 지름 $2 \mathrm{~m}$ 까지 자라고 수피는 홍갈색이며 편백나 무는 주로 조림용이나 관상수 방풍목으로 이용되어 왔다. 일 반적으로 정유는 terpene, alcohol, aldehyde 등과 같은 여러 가지 복합화합물로서 이런 복합물질로 구성된 성분들이 질 병을 치료하는데 광범위한 효능을 갖고 있다. 정유 성분 중 일부분은 약간의 부작용을 일으키지만 정유에는 많은 유효 한 성질과 성분을 갖고 있다. 정유 성분에 의한 효능은 항염 증성, 살균성, 식욕증진, 건위, 강장성, 순환촉진성, 탈취성, 거담성, 살충성, 신경안정성 등이 현재 알려지고 있다 $[7,8]$. 편백나무의 정유 성분의 특성이나 조성에 관해서는 일본산 및 대만산 편백나무를 중심으로 연구 되어져 있으며, 이들의 주요 구성성분은 monoterpene류와 sesquiterpene류인 것으로 밝혀졌다 [9]. $\mathrm{Kim}$ 등은 알레르기 예방 효과 등을 확인하기 위해 아토피성 피부염 증상을 가진 사람의 혈액 중에 집먼지 진드기에 대한 면역 $\mathrm{IgE}$ 에 속하는 항체와 집먼지 진드기 알 레르겐의 원인를 검토 했다. 또한 편백 정유는 아토피, 알레 르기 등 각종 피부질환의 원인이 되는 집먼지 진드기 생육 억제에 탁월한 효과가 있을 뿐 아니라, 피부질환에서 가장 괴로운 증상인 가려움증을 크게 경감시켜 준다고 보고하였 다 [10]. 그러나 추출방법에 따른 편백 정유를 주성분으로 한 기능성 화장품을 제조하여 아토피 효과에 대한 연구는 미비 한 실정이다.

따라서 본 연구는 첫째 연속 수증기 추출 및 초임계 추출 방법에 따른 편백 정유 성분을 비교하고 항산화 효과를 검토 하였다. 둘째, 아토피염을 가진 환자들에게 편백 정유를 주 성분으로 한 세정용 천연 고형 비누와 액상 스프레이, 콜레 스테롤, 세라마이드, 지방산을 혼합한 유액(로션) 제품 등을 제조하여 환부에 도포하여 외용 치료제로서 안정성과 유효 성을 검토하였다.

\section{2. 재료 및 방법}

\section{1. 재료}

편백 (Chamaecyparis obtuse)잎을 2011년 8월에 전남 장성 지역에서 채취해서 연속수증기 추출법 및 초임계 추출법을 이용하여 추출한 정유(Essential oil)를 사용하였다.

\section{2. 추출}

\subsection{1. 연속수증기 추출법}

Likens \& Nickerson type 연속 수증기 증류장치를 이용하여 추출하였다. 편백잎 $200 \mathrm{~g}$ 을 잘게 세절하여 플라스크에 넣고 증류수 $1,000 \mathrm{~L}$ 를 넣은 후, 용매용 둥근바닥플라스크 $(250$ $\mathrm{mL}$ )에는 diethyl ether $100 \mathrm{~mL}$ 를 가하였다. 시료가 들어 있는 플라스크를 $100^{\circ} \mathrm{C}$ 에서 먼저 가온하였고, 시료가 끓기 시작할 때 용매용 플라스크를 $60^{\circ} \mathrm{C}$ 로 가온하였다. 3 시간 동안 추출 후 용매용 플라스크에 들어 있는 diethyl ether만을 분리하여 회전감압 농축기(EYELA NE-1101)를 이용하여 농축하였다.

\subsection{2. 초임계추출법}

초임계 지방 추출 장치 $\left(\mathrm{SCCO}_{2}\right.$ Extraction System, IL Sin, Korea)로 추출하였다. 시료 추출기에 편백잎 $200 \mathrm{~g}$ 을 넣고, 압력 $420 \mathrm{~atm}$, 추출온도 $45^{\circ} \mathrm{C}$ 에서 5 시간 동안 추출하였다.

\section{3. 정유성분 분석}

정유의 휘발성 향기성분의 분석과 동정에는 GC-FID (HP 6890, Hewlett-Packard, Palo Alto, CA, USA)와 GC-MS (7890A GC-5975C MS, Agilent technology, Palo Alto, CA, USA)를 사용하였다. GC-FID에 사용된 capillary column은 HP-5 (30 m×0.32 mm×0.25 $\mu \mathrm{m}, \mathrm{J} \& \mathrm{~W}$, Folsom, CA, USA)이 었다. 초기 오븐 온도는 $40^{\circ} \mathrm{C}$ 에서 3 분간 유지한 후에 $10^{\circ} \mathrm{C} /$ $\mathrm{min}$ 의 속도로 상승시켜 최종온도 $230^{\circ} \mathrm{C}$ 에서 5 분간 유지하였 고 carrier gas는 helium $(2.2 \mathrm{~mL} / \mathrm{min})$ 을 사용하였다. 향기성 분이 흡착된 SPME fiber를 FID가 설치된 $\mathrm{GC}$ 주입구에 넣어 5 분간 탈착시켜 splitless mode로 분석하였다. 분리된 성분의 동정을 위해 $\mathrm{GC}$ 와 연결된 mass spectrometer (Agilent 5975C) 와 HP-5MS column $(30 \mathrm{~m} \times 0.25 \mathrm{~mm} \times 0.25 \mu \mathrm{m}, \mathrm{J} \& \mathrm{~W})$ 을 사용 하였다. 초기 오븐 온도는 $40^{\circ} \mathrm{C}$ 에서 4 분간 유지한 후에 $5^{\circ} \mathrm{C} /$ $\mathrm{min}$ 의 속도로 상승시켜 최종온도 $230^{\circ} \mathrm{C}$ 에서 5 분간 유지하였 고 carrier gas는 helium $(1.0 \mathrm{~mL} / \mathrm{min})$ 을 사용하였다. MS의 이 온화는 $70 \mathrm{eV}$ 에서 실행하였고 splitless mode로 분석하였다. 분리성분의 최종 확인은 GC-MS의 library (Wiley/NBS)와 C6-C22의 n-paraffine mixture (Supelco)를 통한 retention indices의 계산결과를 참고하여 결정하였다.

\section{4. 항산화 효과}

희석한 추출액 $10 \mathrm{~mL}$, methanol $90 \mathrm{~mL}, \mathrm{DPPH}(0.3 \mathrm{mM}) 100$ $\mathrm{mL}$ 혼합해서 30 분간 암실에서 incubation하여 $517 \mathrm{~nm}$ 에서 흡광도를 측정하였다. 계산식은 다음과 같다. 
항산화효과 $(\%)=[1-($ 시료 첨가군의 흡광도 / 시료 무첨 가군의 흡광도) $] \times 100$

\section{5. 아토피성 피부염 임상시험자 선정 및 방법}

2012년 9월1일부터 9월30일까지 광주. 전남지역에 거주하는 연구자의 선정 기준에 의해 선정된 남녀노소를 구분 하지 않 은 40 명의 아토피 피부염 환자를 선정하였다. 선정 기준은 다음과 같다. 아토피성 자가 진단 테스트는 서울의 S 한의원 의 진단 테스트에 의해서 수정 보완된 테스트의 20 문항 중 $1 \sim 5$ 개 초기 아토피 피부염, 6 10개 중증 아토피 11개 이상은 심한 아토피로 구분하였으며, 이 중 중증 아토피 증상인 40 명을 선정하여 임상시험 대상으로 하였다 (아토피 자가 진단 테스트의 20 문항 중 11 문항 이상인 사람, 임상시험 기간 중 스테로이드제 또는 항히스타민제, 면역 억제제를 사용하지 않은 사람, 아토피 피부염 외에 다른 피부 질환이 없는 사람). 대상자에 대해 사전 설문 조사를 실시한 후 편백 정유를 이 용하여 제조한 아토치드 비누와 아토치드 스프레이 아토치 드 로션을 사용하게 한 후 설문과 사례 발표로 진행하였다.

\section{6. 아토피 치료를 위한 제품의 조성}

아토피 치료를 위해 편백 정유를 주성분으로 한 아토치드 비 누 (ato-cide soap), 액상 스프레이(ato-cide spray), 로션 (atocide lotion) 제품의 조성은 Table 1 과 같다.

\section{7. 아토피 치료를 위한 제품의 제조방법}

아토치드 비누 (ato-cide soap) 제조 방법: 비누베이스 $90 \mathrm{~g}$ 을 내열 유리에 잘게 썰어 넣어 비누베이스에 열을 서서히 가해 녹여, 1 3분 정도 식힌 다음, 녹인 비누 베이스에 편백정유 $3 \mathrm{~g}$ 로 녹여 비누 베이스에 넣고, 비누 틀에 부어 굳힌 다음 빼 내 사용하였다.

아토치드 스프레이 (ato-cide spray) 제조 방법: 소독한 비이 커에 편백정유와 올리브 리퀴드를 넣어 섞고 정제수 $90 \mathrm{~mL}$ 를 혼합후, 그 다음에 글리세린을 넣고 잘 저어 소독한 스프

Table 1. Compositions of ato-cide soap, ato-cide spray, and atocide lotion

\begin{tabular}{cccc}
\hline \multirow{2}{*}{ Composition } & \multicolumn{3}{c}{ Concentration (g) } \\
\cline { 2 - 4 } & $\begin{array}{c}\text { Ato-cide } \\
\text { soap }\end{array}$ & $\begin{array}{c}\text { Ato-cide } \\
\text { spray }\end{array}$ & $\begin{array}{c}\text { Ato-cide } \\
\text { lotion }\end{array}$ \\
\hline Soap base & 90.0 & & \\
C. obtusa & 3.0 & 0.5 & 0.5 \\
Essential oil & & 1.0 & \\
Olive liquid & 1.0 & 90.0 & 85 \\
water & & & 1.0 \\
Camellia oil & & 1.0 & 3.0 \\
Neem oil & 2.0 & & 0.5 \\
Primrose oil & & 1.5 & 1.0 \\
Olive wax & 1.0 & 5.0 & 1.0 \\
Glycerin & 1.0 & & 1.0 \\
Vitamin E & & 1.0 & 1.0 \\
Ceramide liquid & 1.0 & & 1.0 \\
Allantoin & & & 5.0 \\
Vitamin $\mathrm{B}_{5}$ & 1.0 & &
\end{tabular}

레이 용기에 담아 실험에 사용하였다.

아토치드 로션 (ato-cide lotion) 제조 방법: 소독한 비이커 $\mathrm{A}$ 에 camellia oil, neem oil, evening primrose oil, olive wax를 넣어 $75^{\circ} \mathrm{C}$ 에 온도를 맞고 소독한 비이커에 $\mathrm{B}$ 에는 정제수 $85 \mathrm{~mL}$ 를 넣어 온도를 $75^{\circ} \mathrm{C}$ 까지 올린 다음 비이커 $\mathrm{A}$ 와 $\mathrm{B}$ 를 혼합하여 그 다음 glycerin, vitamin $\mathrm{E}$, ceramide liquid, allantoin, vitamin $\mathrm{B}_{5}$ 등의 첨가물을 넣어 고르게 교반하여 온도가 $45^{\circ} \mathrm{C}$ 정도로 내려갈 때까지 잘 저어 준 다음 편백정유를 넣 어 고르게 혼합한 다음 소독한 로션 용기에 담아 실험에 사 용하였다.

\section{3. 결과 및 고찰}

\section{1. 편백잎 수분 및 정유 추출수율}

편백잎의 함수율 및 정유 추출 수율을 측정한 결과는 Table 2 와 같다. 편백잎의 함수율은 $55.4 \%$ 이고 수증기 추출방법에 의한 편백 정유 수율은 $1.2 \%$ 로 나타났다. 이것은 수증기 추 출방법에 의한 일본 산 편백 정유 수율 $1.5 \%$ [11] 및 경상대 학교 (경남 진주시 가좌동) 교내에서 생장되고 있는 편백잎 을 이용하여 정유 추출수율보다는 낮았지만 [12] 전북 전주 지역에서 자란 편백 정유 수율 $0.8 \%$ [13]에 비해 높은 정유 수율을 나타냈다. 이것은 지역적 특성 및 생육의 환경의 차 이라고 사료된다. 초임계 추출방법에 의한 편백 정유 추출물 의 수율은 $2.9 \%$ 였다. 이 수치는 수증기 추출방법 에 의한 수 율보다도 약 2.4 배 증가하였다.

\section{2.연속수증기 증류 및 초임계 추출법에 따른 정유 성분}

일반적으로 식물 추출물의 경우 전처리 방법 및 전처리 과정 및 추출시에 사용한 용매에 따라 검출되는 성분이 달라진다. 정유는 많은 종의 유기화합물이 집합된 형태인 천연물이므 로 유기성분을 잘 용출시키고 보존 추출할 수 있는 최적의 전처리법을 사용해야만 손실을 최소화해 다양한 성분의 정 유 성분과 상대적으로 고농도의 각 성분을 고효율로 얻을 수 있다.

초임계 임계추출법의 경우는 온도를 갑자기 떨어뜨린 후 $\mathrm{CO}_{2}$ 로 세포벽을 깨뜨려 성분을 추출하므로 성분 변형을 막 고 성분 손실을 최소화하는 방법이고 다른 전처리법에 비해 상대적으로 검출되는 성분 종류가 다양하고 각 성분의 검출 농도도 높다고 보고되었다. 그러나 수증기 추출법의 경우 온 도를 가해 시료를 끓여 유기성분을 추출하는 방법이므로 온 도를 가해 끓이는 도중 성분이 변형되거나 손실되는 경우가

Table 2. Moisture content and extraction yield of $C$. obtuse essential oil

\begin{tabular}{lccc}
\hline Material & $\begin{array}{c}\text { Moisture } \\
\text { content } \\
(\%)\end{array}$ & $\begin{array}{c}\text { Extraction yield of } \\
\text { essential oil using } \\
\text { SDE (\%) }\end{array}$ & $\begin{array}{c}\text { Extraction yield of } \\
\text { essential oil using } \\
\text { SFE (\%) }\end{array}$ \\
\hline $\begin{array}{l}\text { C. } \text { obtuse } \\
\text { leaf }\end{array}$ & 55.4 & 1.2 & 2.9 \\
\hline
\end{tabular}


발생할 수 있으며, 물(수용성)에 친화력을 가지는 성분이나 수용성과 지용성의 양쪽성 성질을 가지는 성분의 경우 물에 용해되어 완전 제거되지만 일부분의 지용성 오일층에 남아 있게 되어 농도가 낮아질 수 있다고 보고되고 있다 [14]. 따 라서 본 연구에서는 연속수증기 증류 및 초임계 추출법에 따 른 정유 성분을 비교해 보았다. Table 3 은 편백잎을 이용하여 수증기 및 초임계 추출법으로 추출한 휘발성 향기 성분을 $\mathrm{GC} / \mathrm{MS}$ 로 분석한 결과이다. Table 3 에서 보는 바와 같이 추 출방법에 따라 휘발성 향기 성분과 함량이 많은 차이가 있음 을 알 수 있었다. 편백잎에서 연속 수증기 추출법으로 분리 한 정유에서는 72 종의 성분 중에서 48 종의 성분을 동정하였 다. 수증기 추출방법으로 추출한 정유 성분 중에서는 terpinenyl acetate 와 terpinen-4-ol이 각각 $11.04 \%$ 와 $10.01 \%$ 로 가 장 높았고 그 다음 순으로 bornyl acetate $(7.57 \%)$, gamma-terpinene $(6.02 \%)$, elemol (5.16\%), limonene (4.23\%), sabinene (4.19\%), beta-eudesmol (4.39\%), carene (3.42\%), beta-myrcene (3.29\%), widdrene (3.27\%), camphene (2.07\%), cymene $(2.3 \%)$, alpha-terpineol (2.28\%), cadinen (2.45\%), guaiol $(2.58 \%)$, beyerene $(2.21 \%)$, alpha-thujene $(1.71 \%)$, isoledene $(1.57 \%)$, calamenene (1.56\%), cedrol (1.44\%), alpha-Thujene (1.35\%) 순이 였다. 수증기 추출방법에서는 sabinene hydrate acetate, thujopsene, alpha-bisabolol, germacrene, 1,6-germacradien-5-ol, caryophyllene oxide, androstan, (E)-solanone, alpha-bergamotene, alph-muurolene, dehydroaromadendrene, ledol, tramat, longifolene-(I2)-epoxide-(1), guaiol, alloaromadendrene, pyrimidinetetramine, beta-oplopenone은 검출되지 않았다. 그러나 초임 계 추출법으로 분리한 정유에서는 74 종의 성분 중에서 50 종 의 성분을 동정하였다. 추출한 정유 성분 중에서는 terpinenyl acetate와 elemol이 각각 $13.97 \%$ 와 $13.52 \%$ 로 가장 높았다. 특 히 elemol 수치는 수증기 추출법보다도 약 2.6배 높았다. 그 다음 순으로 bornyl acetate (6.87\%), sabinene (6.5\%), beyerene (5.38\%), limonene (4.75\%), beta-eudesmol (3.33\%), androstan (3.13\%), beta.-myrcene $(2.84 \%)$, widdrene $(2.81 \%)$, cubebene $(2.02 \%)$, germacrene $(2.09 \%)$, caryophyllene $(1.97 \%)$, cedrol (1.84\%), gamma-terpinene (1.82\%), ledol (1.46\%), alpha-terpineol (1.35\%), caryophyllene oxide (1.29\%), globulol (1.24\%), longifolene-(I2)-epoxide-(1) (1.11\%), 1,6-germacradien-5-ol $(1.08 \%)$, beta-pinene $(1.02 \%)$, tramat $(0.88 \%)$, dehydroaromadendrene $(0.87 \%)$, curcumene $(0.84 \%)$, terpinen- 4 -ol $(0.80 \%)$, delta-selinene $(0.77 \%)$, alpha-pinene $(0.75 \%)$, beta-himachalene $(0.74 \%)$, solanone $(0.72 \%)$, cedrene $(0.65 \%)$, guaiol, $(0.65 \%)$, rimuene $(0.59 \%)$, cymene $(0.58 \%)$, (E)-alpha-muurolene $(0.58 \%)$, thujopsene $(0.57 \%)$, beta-elemene $(0.54 \%)$, alpha-thujene $(0.50 \%)$, camphene $(0.50 \%)$, alpha-bergamotene $(0.41 \%)$, terpinolene $(0.38 \%)$, cadinen $(0.38 \%)$, alpha-bisabolol $(0.36 \%)$, pyrimidinetetramine $(0.35 \%)$, sabinene hydrate acetate $(0.34 \%)$, beta-oplopenone $(0.33 \%)$, alloaromadendrene $(0.31 \%)$ 이었다. 초임계 추 출법에서는 carene, phellandrene, alpha-ylangene, guaiol, calamenene, longipinene, isocineole, 2-allyltoluene, ocimene, Iso-
Table 3. Volatile compounds of C. obtuse essential oil

\begin{tabular}{|c|c|c|}
\hline \multirow[t]{2}{*}{ Volatile compounds } & \multicolumn{2}{|c|}{$\begin{array}{c}\text { Concentration } \\
\text { (Relative peak area, \%) }\end{array}$} \\
\hline & SDE method & SFE method \\
\hline alpha-Thujene & 1.35 & 0.5 \\
\hline alpha-Pinene & 1.71 & 0.75 \\
\hline Camphene & 2.07 & 0.5 \\
\hline Sabinene & 4.19 & 6.5 \\
\hline beta-Pinene & 3.12 & 0.99 \\
\hline Carene & 3.42 & \\
\hline beta.-Myrcene & 3.29 & 2.84 \\
\hline Phellandrene & 0.86 & \\
\hline Cymene & 2.3 & 0.58 \\
\hline gamma-Terpinene & 6.02 & 1.82 \\
\hline Terpinolene & 0.45 & 0.38 \\
\hline Limonene & 4.23 & 4.75 \\
\hline alpha-Terpineol & 2.28 & 1.35 \\
\hline Terpinen-4-ol & 10.01 & 0.8 \\
\hline Bornyl acetate & 7.57 & 6.87 \\
\hline sabinene hydrate acetate & & 0.34 \\
\hline Terpinenyl acetate & 11.04 & 13.97 \\
\hline beta-Elemene & 0.23 & 0.54 \\
\hline Cadinen & 2.45 & 0.38 \\
\hline Germacrene & & 2.09 \\
\hline Cubebene & 0.65 & 2.02 \\
\hline Curcumene & 0.67 & 0.84 \\
\hline Caryophyllene & 0.94 & 1.97 \\
\hline Cedrene & 0.22 & 0.65 \\
\hline beta-Himachalene & 0.95 & 0.74 \\
\hline alpha-Ylangene & 0.53 & \\
\hline delta-Selinene & 0.2 & 0.77 \\
\hline Calamenene & 1.56 & \\
\hline Longipinene & 0.95 & \\
\hline Thujopsene & & 0.57 \\
\hline Guaiol & 2.58 & \\
\hline Elemol & 5.16 & 13.52 \\
\hline alpha-bisabolol & & 0.36 \\
\hline Cedrol & 1.44 & 1.84 \\
\hline beta-Eudesmol & 4.39 & 3.33 \\
\hline 1,6-Germacradien-5-ol & & 1.08 \\
\hline Caryophyllene oxide & & 1.29 \\
\hline Globulol & & 1.24 \\
\hline Rimuene & 0.22 & 0.59 \\
\hline (E)-Solanone & & 0.72 \\
\hline Beyerene & 2.21 & 5.38 \\
\hline Widdrene & 3.27 & 2.81 \\
\hline Androstan & & 3.13 \\
\hline Isocineole & 0.22 & \\
\hline 2-Allyltoluene & 0.22 & \\
\hline Ocimene & 0.58 & \\
\hline Isoledene & 1.57 & \\
\hline 1,2-Diethylcyclohexane & 0.29 & \\
\hline Cubenol & 0.52 & \\
\hline alpha-Bergamotene & & 0.41 \\
\hline alpha.-Muurolene & & 0.58 \\
\hline Dehyeroaromadendrene & & 0.87 \\
\hline Ledol & & 1.46 \\
\hline Tramat & & 0.88 \\
\hline Longifolene-(I2)-epoxide-(1) & & 1.11 \\
\hline Guaiol & & 0.65 \\
\hline Alloaromadendrene & & 0.31 \\
\hline Pyrimidinetetramine & & 0.35 \\
\hline beta-Oplopenone & & 0.33 \\
\hline
\end{tabular}


ledene, 1,2-diethylcyclohexane, cubenol 등은 검출되지 않았다. 일반적으로 herb, spice, citrus, fruits 등 대부분의 식물체에 서 얻어진 terpene류를 함유하는 정유에서 독특한 향에 영향 을 미치는 것은 terpene (hydrocarbon)이 아니고 alcohol 또는 ester 등을 포함하는 oxygenated terpene으로 알려져 있다 [15]. Table 4는 휘발성분 중의 terpene류와 oxygenated terpene의 구 성 비율을 나타내었다. 연속수증기 추출법을 이용해서 얻은 정유의 주요 구성성분은 $88 \%$ 이상 terpene류로 구성되어 있 다. 특히 monoterpene류, oxygenated monoterpenes류, sesquiterpenes, oxygenated sesquiterpenes 및 diterpenes이 차지하는 비율은 각각 $37.24 \%, 10.9 \%, 9.61 \%, 0.22 \%, 0.22 \%$ 이었다. Hong등 [12]은 전북 전주에서 자란 편백의 잎에서 분리한 정 유의 구성 성분 중에서 $95 \%$ 이상의 terpene류로 구성되어 있 고 monoterpene류, oxygenated monoterpenes류, sesquiterpenes, 및 oxygenated sesquiterpenes이 차지하는 비율은 각각 $36.59 \%$, $29.85 \%, 4.43 \%, 20.74 \%$ 라고 보고하였다. 그러나 전남 장성에 서 채취한 편백잎을 이용하여 초임계 추출방법으로 추출할 경우 정유성분 중에서 monoterpene류, oxygenated monoterpenes류, sesquiterpenes, oxygenated sesquiterpenes, 및 diterpenes이 차지하는 비율은 각각 $19.1 \%, 23.3 \%, 22.66 \%, 1.31 \%$, $10.57 \%$ 이었다. 연속수증기법에 의한 추출물의 경우 oxygenated terpene 함량이 초임계추출물보다도 훨씬 많은 양을 나 타내고 있다. oxygenated terpene의 경우 산소의 존재로 인하 여 terpene의 경우보다도 극성을 띠고 있어서 비극성인 초임 계 이산화탄소보다도 물에 더 잘 추출된 것으로 사료된다. 이는 Nykanenn 등 [16]이 angelica root oil의 수증기 증류에 의한 추출의 경우가 초임계 추출 경우보다도 oxygenated terpene의 추출량이 더 많았다고 한 보고와도 일치하였다. 본 연구에서는 sesquiterpene류 성분들이 초임계 추출시보다도 수증기 추출시에 훨씬 적게 나타나고 있다. 이는 이들 성분 들이 상대적으로 휘발도가 낮아서 수증기 증류시 파괴되거 나 일부는 물에 가수 분해되었음을 시사하며 이로 인하여 향 의 변질이 일어났을 것으로 생각된다.

Jung 등 [13]은 편백 추출물에서는 총 24종의 휘발성 향기 성분이 검출되었으며 휘발성 향기 성분은 alpha-terpinenyl acetate $14.9 \%$, sabinene $10.9 \%$, dl-limonene $9.6 \%$, alpha-terpinolene $7.5 \%$, alpha-pinene $7.1 \%$ 로 monoterpene류가 약 $83.7 \%$, sesquiterpene류는 약 $16.3 \%$ 의 비율을 차지하는 것으로 확인 되었다고 보고했다. 또한 일본산 편백 잎에서 분리된 편백 추 출물에서 monoterpene류가 $47.5 \%$, sesquiterpene류가 $43.2 \%$, 산류와 페놀류 등 기타성분이 약 $9.3 \%$ 를 차지한다는 연구보

Table 4. Relative percentage of various classes of compounds in C. obtuse essential oil obtained by SDE and SFE

\begin{tabular}{ccc}
\hline Compounds class & $\begin{array}{c}\text { SDE method } \\
(\%)\end{array}$ & $\begin{array}{c}\text { SFE method } \\
(\%)\end{array}$ \\
\hline Monoterpenes & 37.4 & 19.1 \\
Oxygenated monoterpenes & 10.9 & 23.33 \\
Diterpenes & 0.22 & 10.57 \\
Sesquiterpenes & 9.61 & 22.66 \\
Oxygenated sequiterpenes & 0.22 & 1.31 \\
\hline
\end{tabular}

고 [17]와 일본산 편백 잎에서 분리한 정유의 중성성분 분획 에서 monoterpene류의 비율은 58.9\%, sesquiterpene류의 비율 은 $41.1 \%$ 라고 보고된 결과 [18]와는 다른 결과를 나타냈다. 이는 편백의 품종, 편백잎의 채취 시기, 추출 증류방법 등의 차이 때문인 것으로 생각된다. 편백 추출물에서 확인된 monoterpene류와 sesquiterpene류는 항바이러스, 항균성을 나타내 고 천연 방제제로서의 효능을 가진다는 연구결과가 있으며 특히 sesquiterpene류는 monoterpene류보다도 구조가 다양하 고 항진균, 진통효과가 높다고 알려져 있다 [19]. 초임계 방법 으로 추출한 정유의 성분 중에서 sesquiterpene류 함량은 monoterpene류 보다도 약 2.5배 높았다. 또한 dl-limonene는 낮 은 농도에서 아플라톡신 억제효과 [20], pinene 은 높은 항헬 리코박터 파일로리 활성을 가진다는 연구 보고도 있다 [21].

\section{3 연속수증기 및 초임계 추출법에 따른 정유의 항산화 활성}

지질의 과산화 과정 중 만들어진 라디칼은 암, 동맥경화 등 과 같은 많은 질병을 유발하며, 인체의 노화를 촉진시킨다 [22]. 천연물에 있는 페놀 화합물 및 플라보노이드 등은 이러 한 라디칼에 수소를 공여하여 라디칼을 환원시키거나 상쇄 함으로써 지질 산화를 억제할 수 있다. DPPH는 화합물내 질 소 중심의 radical로 free radical의 안정화된 물질이다. 따라 서 반응 중 $\mathrm{DPPH}$ 의 감소는 free Radical의 소거 반응이 진행 되고 있음을 알 수 있고 지질의 과산화 초기반응의 억제 정 도를 예측할 수 있다. DPPH는 free radical을 가지고 있는 수 용성 물질로서 $515 \sim 520 \mathrm{~nm}$ 부근에서 최대 흡광도를 가지며 항산화 활성이 있는 물질과 만나면 전자를 내어주며 radcal 이 소거되고 탈색된다. 이러한 $\mathrm{DPPH}$ 는 dioxane이나 $\mathrm{CCl}_{4}$ 와 같은 비극성 용매에서는 2 차, 3 차 산화 반응이 일어나기도 하나 DPPH의 질소 원자와 alcohol에는 수소 결합이 형성되 기 때문에 alcohol용액 내에서는 비교적 안정하다 [23]. 연속 수증기 및 초임계 추출법에 따른 정유의 항산화효과를 알아 보기 위해 $\mathrm{DPPH}$ 라디칼 소거능을 측정했고 그 결과를 Fig. 1 에 나타내었다. $\mathrm{DPPH}$ 라디칼 소거능은 정유의 농도에 각각 비례하였다. 수증기 추출법에 의해 추출된 정유의 경우에는 농도가 $20 \mu \mathrm{L} / \mathrm{mL}$ 에서 $80 \mu \mathrm{L} / \mathrm{mL}$ 로 증가할 경우 $\mathrm{DPPH}$ radi$\mathrm{cal}$ 소거능은 $10.5 \%$ 에서 $55.1 \%$ 으로 증가하였으며, 그 이후 에서는 평형상태를 유지하였다. 초임계추출법에 의해 추출

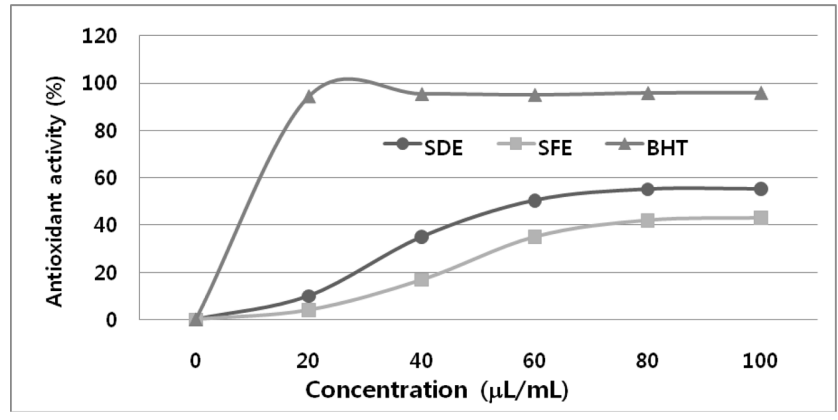

Fig. 1. Effect of essential oil concentration on antioxidant activity. 
된 정유의 경우에는 농도가 $20 \mu \mathrm{L} / \mathrm{mL}$ 에서 $80 \mu \mathrm{L} / \mathrm{mL}$ 로 증가 할 경우 DPPH radical 소거능은 $4.3 \%$ 에서 $42.8 \%$ 으로 증가하 였으며, 이 경우에서도 그 이후의 농도에서는 평형상태를 유 지하였다. 이상의 결과로부터 수증기 추출법에 의한 정유 성 분이 항산화 효과가 높은 것을 알 수 있었으며, 이는 monoterpene 농도가 초임계 추출법에 의한 것보다 더 높았기 때문 으로 사료된다. 이러한 결과는 Germann 등 [24]이 정유 성분 중에서 monoterpene이 주로 활성을 갖는다는 결과와 일치하 였다. 또한 정유 성분중에서 높은 항산화 활성을 나타내는 주요 활성 물질로는 gamma-terpinene, alpha-terpinene, terpinolene 같은 terpene이 보고되고 있다 [25]. 연속수증기 추출 법에 의해 추출한 정유 성분 중에서 gamma-terpinene, terpinolene의 농도는 초임계 추출법보다도 약 2.9 배 높았다. 그러 나 편백정유는 휘발성으로 인해 효능이 오래 지속되지 않는 다는 제한 효소를 가지고 있어 사용되는 용도에 따라 올바른 제형과 변형 혹은 가공방법의 선택이 중요하다고 사료된다.

\section{4. 아토피성 피부염 임상효과}

본 연구에서는 스트레스 완화 작용과 면역기능을 증대시키 고 알레르기 및 피부질환에 효능이 있는 것으로 알려진 피톤 치드 (phytoncide)의 함량이 가장 높은 것으로 보고된 편백 정유를 주성분으로 한 세정용 천연 고형비누와 액상 스프레 이, 콜레스테롤, 세라마이드, 지방산을 혼합한 유액 (로션) 제 품 (ato-cide)을 피부건조증, 짓무름증, 가려움증을 호소하는 아토피 피부염 환자의 환부에 4 주간 도포하게 하여 외용 아 토피 개선 기능성 화장품으로서의 안정성과 아토피 증상이 개선되는 효능을 검증하기 위해 아토피 피부염 환자에게 적 용한 편백 정유를 주성분으로 한 천연 고형 비누와 스프레이, 아토치드 로션의 안정성과 아토피 증상의 개선 효능에 대해 검토하였다.

Gwak 등 [26]은 편백정유 성분 중 sesquiterpene류는 monoterpene류보다 구조가 다양하고 항진균, 진통 등 다양한 생리 활성에 효과가 높다고 보고했다. 따라서 초임계 추출법에 의 해서 추출한 정유을 이용하여 아토피성 피부 증상 개선을 위 한 편백 정유의 효능을 검증하기 위하여 비누와 스프레이, 로 션을 제조하여 도포 후 설문지 답변과 사례 발표를 통해 연구 를 진행하였다. 그 결과를 Table 5와 Fig. 2에 나타내었다. 사 용 후 개선효과에 관한 질문에서 매우 좋아졌다 $(35.0 \%)$, 좋 아졌다 $(30.0 \%)$, 조금 좋아졌다 $(25.0 \%)$, 잘 모르겠다 $(7.5 \%)$, 더 심해졌다 $(2.5 \%)$ 의 응답을 했고 $65 \%$ 이상의 대상자가 좋 아졌다 라는 응답을 해 편백 정유의 비누와 스프레이, 로션 등의 효능이 임상시험대상자들에게서 매우 유의함을 보여 주었고 제품의 개선 요구 사항에 관한 질문에서는 보습력의 지속 $(65.0 \%)$, 유분감의 지속 $(12.5 \%)$, 향의 지속성 $(20 \%)$, 자 극성 완화 $(0 \%)$ 의 응답을 보였다.

이는 보습력의 지속이 $65 \%$ 의 높은 응답을 보인 원인은 계 절적으로 더위가 채 가시지 않은 8월쯤 제품 성분을 구성하 여 더위에 끈적이지 않도록 성분을 조성했던 요인과 아토피 피부염 환자들의 대부분이 공통적으로 호소하는 있는 심한
Table 5. Effect of ato-cide soap, ato-cide spray, and ato-cide lotion on skin condition

\begin{tabular}{ccc}
\hline & Item of test & Skin condition (\%) \\
\hline & 매우 좋아졌다 & 35.0 \\
제품도포 후 & 좋아졌다 & 30.0 \\
효과 & 조금 좋아졌다 & 25.0 \\
& 잘 모르겠다 & 7.5 \\
& 더 심해졌다 & 2.5 \\
\hline 제품이 & 보습력 지속 & 65.0 \\
개선되어 할 & 유분감 지속 & 12.5 \\
부분 & 향의 지속성 & 20.0 \\
& 자극성 완화 & 0 \\
\hline \multirow{3}{*}{ 도포한 제품의 } & 가려움증 개선 & 65.0 \\
가장 큰 효과 & 건조증 개선 & 27.5 \\
& 짓무름증 개선 & 5.0 \\
& 흥터완화 & 2.5 \\
\hline \multirow{3}{*}{ 도포한 제품의 } & 제품의 효능 효과 & 65.0 \\
가장 큰 장점 & 제품의 향 & 10.0 \\
& 제품의 용기 & 0 \\
& 제품의 안정성 & 25.0 \\
\hline
\end{tabular}

건조증이 주요요인으로 작용한 것으로 보여진다.

또 자극성의 완화의 질문에 $0 \%$ 의 응답을 보인 부분에서는 편백 정유의 제품이 마우스 경구 투여 실험에서 보여준 결과 와 마찬가지로 아토피성 피부에도 유의한 효과를 보일 것이 라는 연구자의 생각과 일치함을 보여 주었다. 도포했던 제품 의 가장 큰 효과를 묻는 질문에서는 가려움증 개선 $(65.0 \%)$, 건조증 개선 (27.5\%), 짓무름증 개선 (5.0\%), 흥터완화 (2.5\%) 의 응답을 보여 이는 아토피성 피부염을 가진 사람의 가장 큰 고통인 심한 소양증을 보였던 결과를 볼 때 편백 정유의 제 품이 아토피성 피부의 환우들의 고통을 덜어주는 데 매우 유 의한 제품이라는 결론을 보여주고 있다. 도포 제품의 가장 큰 장점을 묻는 질문에서는 제품의 효능 효과 $(65.0 \%)$, 제품 의 향 $(10.0 \%)$, 제품의 용기 $(0 \%)$, 제품의 안정성 $(25.0 \%)$ 의 응 답을 보였다. 이는 제품의 안정성과 효능 효과에 대한 응답 자들의 신뢰를 볼 수 있었다. 여러가지 주관적이고 객관적인 결과들을 보면 초임계 방법에 의해 추출한 편백정유가 아토 피 증상 환우들의 가장 큰 고통으로 손꼽는 가려움증 완화로 상당한 효과를 보이는 것으로 확인되었으나 여러 가지 변수 에 예민한 반응을 보이는 아토피성 피부염의 특성으로 볼 때 완치시킨다는 것은 어렵지만, 치료 보조용 화장품으로의 유

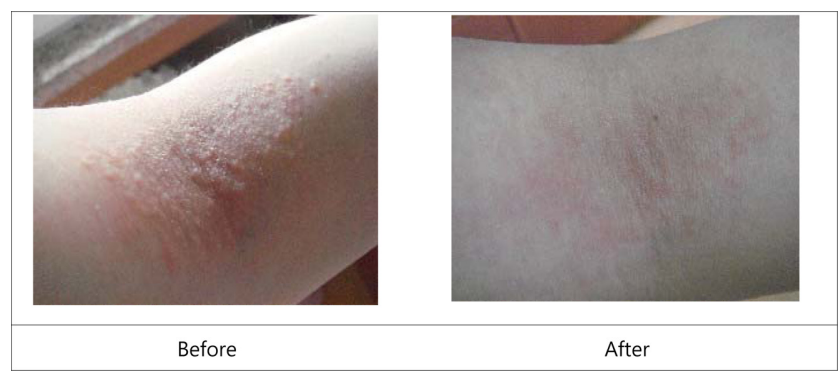

Fig. 2. Skin morphlogy after and before use of ato-cide soap, atocide spray, and ato-cide lotion. 
효성은 가치가 있다고 사료된다. 그러나 본 연구자의 연구 대상자 중의 한 여고생은 연구 과정 중 아토피 개선 반응에 서 좋은 호전 반응을 보이다가 시험을 앞두고 급격히 악화 되는 증상을 보였다. 이는 스트레스가 인체의 면역기능을 저 하시켜 아토피 피부염에 유해하기 때문으로 사료된다. 또한 본 연구는 아토피 피부염을 가진 환자들에게 독성평가 결과 무독성으로 알려졌으며 강한 살균작용과 숲의 수목향기로 심신의 안정을 주며, 또한 스트레스 완화 작용과 면역기능을 증대시키고 알레르기 및 피부질환에 효능이 있는 것으로 검 증된 피톤치드 (phytoncide)의 함량이 가장 높은 것으로 보고 된 편백 정유를 주성분으로 하여 세정용 천연 고형 비누와 액상 스프레이, 유액(로션)의 제품 등을 제조하여 환부에 도 포함으로서 외용 치료제로서 안정성과 유효성을 확인하여 편백정유의 아토피성 피부증상 개선에 다양한 제품 유형으 로의 활용 가능성이 있다고 사료된다.

\section{4. 결론}

연속 수증기 추출 및 초임계 추출 방법에 따른 편백 정유 성 분 및 항산화 효과를 비교하고 아토피염을 가진 환자들에게 편백 정유를 주성분으로 한 기능성 화장품을 제조하여 환부 에 도포하여 외용 치료제로서 안정성과 유효성을 검토하였 다. 연속수증기 추출법을 이용해서 얻은 정유의 주요 구성성 분은 $88 \%$ 이상이 terpene류이었다. 특히 monoterpene류, oxygenated monoterpenes류, sesquiterpenes, oxygenated sesquiterpenes 및 diterpenes이 차지하는 비율은 각각 $37.24 \%, 10.9 \%$, $9.61 \%, 0.22 \%, 0.22 \%$ 이었다. 초임계 추출방법으로 추출할 경우는 monoterpene류, oxygenated monoterpenes류, sesquiterpenes, oxygenated sesquiterpenes, 및 diterpenes이 차지하는 비 율은 각각 $19.1 \%, 23.3 \%, 22.66 \%, 1.31 \%, 10.57 \%$ 이었다. 연 속수증기법에 의한 추출물의 경우 oxygenated terpene 함량 이 초임계 추출물보다도 훨씬 많은 양을 나타내었다. oxygenated terpene의 경우 산소의 존재로 인하여 terpene의 경우보 다도 극성이 커서 비극성인 초임계 이산화탄소보다도 물에 더 잘 추출되며, 수증기 추출법에 의한 정유 성분이 항산화 효과가 높은 것은 monoterpene 농도가 초임계 추출법에 의한 정유보다 더 높기 때문이다. 또한 초임계추출법으로 추출한 편백 정유를 혼합하여 제조한 화장품은 아토피 환우들에게 가장 큰 고통인 가려움증 개선 및 피부보습력을 증진시키는 등의 효과를 나타내어 안정적인 아토피 피부염 개선 물질 및 기능성화장품의 원료로서 적용 가능성이 있음을 확인하였 다.

\section{REFERENCES}

1. Reineccius, G. A. (2007) Flavour-isolation techniques: Chemistry, Bioprocessing, and Sustainability. Berger RG (ed). pp. 409-
414, Springer-Verlag, Berlin, Germany.

2. Yun, K. S., J. H. Hong, and Y. H. Choi (2006) Characteristics of Elsholtzia splendens extracts on simultaneous steam distillation extraction conditions. Korean J. Food Preserv. 13: 623-628.

3. Choi, Y. H., J. Kim, and K. P. Yoo (1999) Selective extraction of ephedrine from Ephedra sinica using mixture of $\mathrm{CO}_{2}$ diethylamine and methanol. Chromatographia. 50: 673-679.

4. Choi, Y. H., J. H. Ryu, K. P. Yoo, Y. S. Chang, and J. Kim (1989) Supercritical carbon dioxide extraction of podophyllotoxin from Dysosma pleinatha roots. Planta Med. 64: 482-483.

5. Lucien, F. P. and N. R. Foster (2000) Solubilities of solid mixtures in supercritical carbon dioxide: A review. J. Supercrit. Fluid. 17: 111-134.

6. Hubert, P. and O. G. Vitzthum (1978) Fluid extraction of hop, spices, and tobacco with supercritical gases. Angew. Chem. Int. Edit. 17: 710-715.

7. Mishra, A. K. and N. K. Dubey (1994) Evaluation of some essential oils for their toxicity against fungi causing deterioration of stored food commodities. Appl Environ Microbiol . 60(4):1101-1105.

8. Price, S., L. Price, and S. Pe'noel D (1995) Aromatherapy for Health professionals. 1st ed., pp. 133-167. Chrchill Livingstone, New York.

9. Hayashi, S., K. Yano, and T. Matsuura (1964) The monoterpene constituents of the essential oil from hinoki (Chamaecyparis obtusa). Bull.Chem.Soc.Japan. 37: 608-683.

10. Kim, Y. Y. (2006) Health and phytoncide of forest, Res. J. Cheju National Univ. 35: 302-307.

11. Lin, T. C., J. M. Fang, and Y. S. Cheng (1999) Terpenes and lignans from leaves from Chamaecyparis formosensis. Phytochem. 51: 793-801.

12. Hong, C. U., C. S. Kim, N. G. Kim, and Y. H. Kim (2001) Composition of essential oils from the leavesand the fruits of Chamaecyparis obtusa and Chamaecyparis pisifera. Korean Soc. Agric. Chem. Biotechnol. 44: 116-121.

13. Jung, J. Y., J. W. Kim, Y. S. Kim, H. M. Park, B. H. Lee, M. S. Choi, and J. K. Yang (2012) Antifungal activity of extracts from Chamaecyparis obtusa and Pseudotsuga menziesii against Trichoderma spp. J. Agr. Life Sci. 45(4): 1-11.

14. Chang, M. J. and S. R. Lee (2009) A comparative study on the compositions of Hwangryeonhaedok-tang's essential oils obtained by supercritical carbon dioxide extraction and hydrodistillation methods. J. Meridian Acupoint. 26: 211-223.

15. Eskin, N. A. M. (1979) Terpenoids and flavonoids: Flavor and textures: The chemistry and biochemistry of selexted compounds, pp. 69-93. Academic press, New York, U.S.A.

16. Nykanen, I., L. Nykanen, and M. Alkio (1991) Composition of angelica root oils obtained by supercritical $\mathrm{CO}_{2}$ extraction and steam distillation. J. Ess.Oil Rs. 3: 229-236.

17. Hayashi, S., K. Yano, and T. Matsuura (1964) The monoterpene consituents of the essential oil from hinoki (Chamaecyparis obtusa). Bull. Chem, Soc. Japan 37: 474-476.

18. Shieh, B., Y. lizuka, and Y. Matsubara (1981) Monoterpenenoid and sesquiterpenoid consituents of the essential oil of hinoki (Chamaecyparis obtuse). Agric. Biol. Chem. 45: 1497-1499.

19. Carson, C. F. and T. V. Riley (1995) Antimicrobial activity of the 
major components of the essential oil of Melaleuca alternifolia. J. Appli. Bacteriol. 78: 264-269.

20. Singh, P., R. Shukla, B. Prakash, A. Kumar, S. Singh, P. K. Mishra, and N. K. Dubey (2010) Chemical profile, antifungal, antiaflatoxigenic and antioxidant activity of Citrus maxima Burm. and Citrus sinensis (L.) Osbeck essential oils and their cyclic monoterpene, DL-limonene. Food Chem. Toxicol. 48: 1734-1740.

21. Rozza, A. L., D. M. Moraes, T., Kushima, H., Tanimoto, A., Mayo Marques, M. O., Bauab, T. M., Hiruma-Lima, and C. H. Pellizzon (2010) Ariane Leite Rozza, Thiago de Mello Moraes, Helio Kushima, Alexandre Tanimoto, Marcia Ortiz Mayo Marques, Tais Maria Bauab, Clelia Akiko Hiruma-Lima, Claudia Helena Pellizzon. 6: 1380-1387.

22. Dorman, H. J., M. Kosar, K. Kahlos, Y. Holm, and R. Hiltunen
(2003) Antioxidant properties and composition of aqueous extracts from Mentha species, hybrids, varieties, and cultivars. J. Agr. Food Chem. 51: 4563-4569.

23. Decker, E. A. (1997) Phenolics: prooxidants or antioxidants. Nutrition Review. 55: 396-407.

24. Germann. (2005) Terpenoids as plant antioxidants, Vitamins Hormones. 72: 505-535.

25. Choi, H. S., H. S. Song, H. Ukeda, and M. Sawamura (2000) Radical-scavenging activities of citruss essential oils and their components. J. Agr. Food Chem. 48: 4156-4161.

26. Gwak, K. S., M. J. Park, E. B. Jeung, J. W. Chang, and I. G. Choi (2006) Comparison of antifungal activities of monoterpenes and sesquiterpenes in essential oil from Chamaecyparis obtuse against dermatophytes. Mokchae Konghak. 34: 46-55. 